УДК 811.111 '42

\title{
ОСНОВНІ ПРИНЦИПИ АНАЛІЗУ ПСИХОТЕРАПЕВТИЧНОГО ДИСКУРСУ: МОВНИЙ АСПЕКТ
}

\author{
КАЧМАР О. Ю. \\ кандидат філологічних наук, доцент \\ ДВНЗ “Ужгородський національний університет” \\ olga.kachmar@uzhnu.edu.ua
}

\begin{abstract}
Статтю присвячено дослідженню мовного аспекту аналізу психотерапевтичного дискурсу. Сформульовано основні принципи аналізу психотерапевтичного дискурсу, визначено роль взаємозв'язку між картиною світу особистості та її психологічними проблемами в процесі продукування висловлювань. Докладно схарактеризовано комунікацію у психотерапевтичному дискурсі, на основі чого витлумачено іiі як мовну форму цілеспрямованої соціальної дії.

Унаслідок виконаного аналізу встановлено динаміку мовних засобів реалізації основних принципів аналізу психотерапевтичного дискурсу із залученням опису тактикостратегічного потенціалу. Виявлено, що семантичний простір мови, об'єктивований у системних одиницях мовної картини світу, та характер комунікації взаємовизначаються типом дискурсу, у якому відбувається комунікація, та структурою мовних особистостей.

Трактування комунікації під час психотерапевтичних бесід засноване на діяльнісному розумінні дискурсу. Така інтерпретація прив'язана до кожної конкретної прагматичної ситуації та ментальних процесів терапевта й клієнта, виражених вербально тактикостратегічним потенціалом.

У статті також обгрунтовано тезу про те, що замовчування нарівні з вербально вираженими комунікативними стратегіями й тактиками відіграє конститутивну роль в аналізі психотерапевтичного дискурсу, а саме вказує на важливі складники внутрішнього досвіду суб'єкта.

Ключові слова: дискурс, аналіз, принцип, психотерапевтичний дискурс, комунікативна стратегія, тактика.
\end{abstract}

\section{MAIN PRINCIPLES OF PSYCHOTHERAPEUTIC DISCOURSE ANALYSIS: LINGUISTIC ASPECT}

KACHMAR Olha Yuriivna

$\mathrm{PhD}$ in Philology, Associate Professor, Uzhhorod National University olga.kachmar@uzhnu.edu.ua

Introduction. The article deals with the linguistic aspect of the basic principles of psychotherapeutic discourse analysis. Research on discourse is one of the priorities in modern linguistics. Integrative processes in science generally are based on the expansionism of anthropocentric linguistics and they contribute to the formation of a cognitive-communicative paradigm of knowledge, where discursive activity is seen in the light of internal mental processes. Psychotherapeutic interaction of both participants in the process - the therapist and the patient - is interpreted as a discursive practice that requires a thorough linguistic analysis to identify the motivational, cognitive and communicative aspects of the speech activity of both participants in the psychotherapeutic session, and that determines the relevance of our research.

The purpose of the article is to highlight the content and linguistic specificity of the main principles of psychotherapeutic discourse analysis.

The methodology for the analysis of psychotherapeutic discourse involves the definition and description of the communicative strategies implemented in the discourse, based on expansionism, anthropocentrism, functionalism and explanatory. The basic principles of 
psychotherapeutic discourse analysis do not depend on a specific psychotherapeutic school, since the isolation of tactical and strategic potential is determined by the specificity of psychotherapeutic communication, according to the distribution of communicative roles and positions of the participants in the therapeutic process, their expectations, the dynamics of language initiatives, message sequencing, listening and understatement.

As a result of the research, the role of the correlation between the personality's worldview and his psychological problems in the process of production of statements is determined. The communication in psychotherapeutic discourse is described in terms of a linguistic form of purposeful social activity. The article establishes the dynamics of linguistic means for realization of the basic principles of psychotherapeutic discourse analysis with the description of tactical and strategic potential.

Summing up, the author arrives at the following conclusions: 1) the semantic space of the language, objectified in the system units of the linguistic worldview, and the nature of communication are mutually determined by the type of discourse within which the communication is carried out, and the structure of language personalities; 2) interpretation of communication during psychotherapeutic sessions is based on considering the discourse as the social interaction. Such an interpretation is tied to each specific pragmatic situation and the mental processes of the therapist and the client, verbalized in tactical and strategic potential; 3) along with verbally expressed communicative strategies and tactics, the revealed understatement plays a constitutive role in the analysis of psychotherapeutic discourse, i.e., it points to the important components of the internal experience of the subject. The patient's speech often includes hushing up that corresponds to deeply displaced layers of the unconscious.

Keywords: discourse analysis, principle, psychotherapeutic discourse, communicative strategy, tactics.

Формулювання проблеми та обгрунтування актуальності їі розв'язання. Дослідження дискурсу є одним із пріоритетних напрямів сучасного мовознавства. Інтегративні процеси в науці загалом засвідчують експансіонізм антропоцентричної лінгвістики й сприяють становленню когнітивно-комунікативної парадигми знань, де дискурсивна діяльність розглядається на тлі внутрішніх ментальних процесів (Кубрякова, 1995 с. 207).

Антропоцентричність лінгвістики, а відповідно й пріоритет фактора людини в мові й мовленні дає підстави трактувати мовну систему та іï функцію як інструмент і результат когнітивно-комунікативної діяльності суб'єкта. Актуальним стає дослідження мови в діяльнісному аспекті: з одного боку, роль мови в отриманні, обробці, закріпленні та збереженні знань про світ кваліфікують як продукт когніції, а з іншого - як засіб передання інформації або інструмент впливу на людину (Gumperz, 1982, p. 15; Levy, 1979, pp. 183-210; Tannen, 1993, p. 383-397).

Аналіз останніх досліджень і публікацій. Психотерапевтичну взаємодію обох учасників процесу - психотерапевта та пацієнта - трактують як дискурсивну практику, спираючись на визначення дискурсу як “тексту, поглиненого життям” (Арутюнова, 1998, с. 36). Аналіз психотерапевтичного дискурсу як форма епістемологічної (пізнавальної) практики сформувався в 60-70-ті роки XX ст. на межі логіки, лінгвістики, психоаналізу й філософії мови. Дослідники Ж. Лакан, Н.Ф. Каліна, О.Т. Соколова, Н.С. Бурлакова та ін. сформулювали цілу низку принципів аналізу відповідного дискурсу, простежили динаміку внутрішнього діалогу пацієнта й навіть описали процес породження смислів у пацієнта під час лікувальних сеансів (Кириллова, 2010, с. 70-78). Однак тексти діалогів як необхідний елемент психотерапевтичного дискурсу потребують також ретельного лінгвістичного аналізу з метою виявлення мотиваційних, когнітивних та комунікативних аспектів мовленнєвої діяльності обох учасників психотерапевтичного сеансу, що й зумовлює актуальність нашого дослідження. 3 використанням аудіо- і відеотехніки для фіксування терапевтичних сеансів зросли можливості точного й повного сприйняття психотерапевтичного дискурсу, а методологічні апарати психології, семіотики та лінгвістики вдало поєднуються в комплекс засобів для його аналізу (Edmondson, 1981, с. 81). 
Мета статті - дослідити основні принципи аналізу психотерапевтичного дискурсу з погляду мовного оформлення.

Досягнення мети передбачає виконання таких завдань:

1) визначити роль взаємозв'язку між картиною світу особистості та ії психологічними проблемами в процесі продукування висловлювань;

2) схарактеризувати комунікацію в психотерапевтичному дискурсі як мовну форму цілеспрямованої соціальної дії;

3) 3'ясувати динаміку мовних засобів реалізації основних принципів аналізу психотерапевтичного дискурсу із залучення опису тактико-стратегічного потенціалу.

Матеріалом дослідження послугували автентичні тексти психотерапевтичних сеансів Карла Роджерса 3 пацієнткою Глорією - 144 висловлювання.

Мета статті зумовила дослідження основних принципів аналізу психотерапевтичного дискурсу 3 опертям на постулати експансіонізму, антропоцентризму, функціоналізму та експланаторності.

Виклад основного матеріалу. Тактико-стратегічний потенціал відповідного дискурсу визначається метою та завданнями психотерапевтичної допомоги. Аналіз змісту висловлювань клієнта передбачає виокремлення несвідомих основ концептів та картини світу, що породжують психологічні труднощі, а також сприйняття лінгвальних і семантичних механізмів продукування висловлювань, у яких відображені усвідомлені чи неусвідомлені проблеми. Картина світу в нашому розумінні - це динамічна когнітивна структура, глобальне уявлення іiі автора про світ, отримане внаслідок узагальнення досвіду пізнання. Це водночас і результат, і регулятивний чинник діяльності людини, зокрема й лінгвокомунікативної, у природному та соціальному середовищах. Визначальна роль картини світу в мові й мовленні зумовлена їі вагомим впливом на:

1) семантичний простір мови, об'єктивований у системних одиницях (мовної картини світу);

2) характер комунікації в іії рольовому аспекті;

3) тип дискурсу, у якому відбувається комунікація;

4) структуру мовної особистості.

Картина світу складається з концептів - “квантів знання” (Кубрякова, 2004, с. 90) і моделюється у вигляді різноманітних концептуальних структур.

Психотерапевтичний дискурс як мовна форма цілеспрямованої соціальної дії прив'язаний до конкретної прагматичної ситуації, яка визначає зв'язність, комунікативну адекватність, а також до ментальних процесів терапевта і клієнта, їхніх суб'єктивних стратегій розуміння і відтворення концептів реальності під час комунікації. Комунікація в такому контексті це цілеспрямована, мотивована, регулятивна семіотична взаємодія, спрямована на встановлення спільних орієнтирів у життєвому просторі на основі загальних смислів - способах і умовах виживання людини. Комунікативна взаємодія забезпечена семантичною сіткою, представленою як єдина система 3 нейронною мережею мозку, що пронизує психічний досвід людини за принципом семантичних ядер через усвідомлювану та неусвідомлювану динаміку асоціативних зв'язків (Как нарисовать портрет птицы, 2017, с. 10).

За умов конкретного соціально-психологічного контексту процес комунікації співвідноситься з поняттям дискурсу. Єдність когнітивного та комунікативного аспектів дискурсу виражається в дискурсивних стратегіях. Стратегія дискурсу - це вербалізований комунікативний намір мовця, що базується на основі знання про загальноприйняті моделі комунікативної поведінки.

Деякі терапевтичні напрями й підходи мають не лише свої окремі способи оформлення мовленнєвого акту, а й відповідний тезаурус (професійний словник), набір визначальних метафор, конвенціональні норми впливу, імпліцитні уявлення тощо. Основні принципи аналізу психотерапевтичного дискурсу не залежать від конкретної психотерапевтичної школи, оскільки виокремлення тактико-стратегічного потенціалу зумовлене специфікою психотерапевтичного 
спілкування, яке визначається розподілом комунікативних ролей і позицій учасників терапевтичного процесу, їхніми очікуваннями, динамікою мовних ініціатив, черговістю мовлення, слухання і мовчання.

До таких принципів належать:

1. Принцип суб'єктності.

Згідно з цим принципом, суб'єктами психотерапевтичного дискурсу можуть бути не тільки терапевт і клієнт, а й група, діада терапевтів. Для терапевта, особливо в аналітичних підходах, дуже важливо з'ясувати, ким насправді є мовна особистість суб'єкта мовлення. У процесі комунікації з пацієнтом психотерапевт з'ясовує основні запитання: “Хто говорить?”, “Чому?” i “Навіщо?”. Від відповідей на них залежать стратегія і тактика терапевтичного аналізу і навпаки: терапевтичний аналіз моделює мовленнєвий тактико-статегічний потенціал. Ці процеси завжди є взаємозумовлюваними, оскільки соціальний статус і конкретні життєві обставини клієнта не завжди достовірно визначають його суб'єктність.

T1 (Rogers stands as Gloria enters.) Good morning.

C1: Hello,

T1 I'm Dr. Rogers, you must be Gloria. (They shake hands and sit down.)

C2 Yes, I am.

T2 Won't you have a chair? Now then, we have half an hour together, and I really don't know what we will be able to make of it but uh I hope we can make something of it. I'd be glad to know whatever concerns you. (T: Sitting forward, C: Sitting back, legs crossed, right arm over the back of the chair)

C3 Well, right now I'm nervous (T: Mhm) but I feel more comfortable the way you are talking in a low voice and I don't feel like you'll be so harsh on me. But, ah ...

T3 I hear the tremor in your voice so I know you are... (C: Smiles)(Roger's Transcripts, Volume 12, Gloria Interview).

Проілюстрований матеріал послідовно відображає різноманітні організаційні вербальні та невербальні комунікативні ходи, а саме:

1) стратегію створення психологічного комфорту клієнта, що втілена тактикою ввічливості / демонстрації поваги (встав, висловив повагу - цим він подіяв і на раціональну, і на емоційну сферу свідомості клієнта, - створив емпатію), тактикою привітання (організаційний вербальний та невербальний - фатичний хід);

2) стратегію створення психологічного комфорту клієнта, що реалізована тактикою щирості: висловлюючи невпевненість, психотерапевт насправді демонструє щирість / усвідомлення складності завдання та скорочує дистанцію між собою і пацієнтом, що засвідчує вживання we; не менш важливою є тактика солідаризації (також через вживання wе): акцентування, що й Глорія є експертом, оскільки це ії життя): а також тактика налаштування на позитивний результат (лікар висловлює надію і налаштовує на позитивний результат);

3) стратегію створення психологічного комфорту пацієнтки, яка актуалізована тактикою підвищення іiї самооцінки шляхом висловлення задоволення від майбутнього спілкування 3 нею, що підвищує її самооцінку;

4) стратегію накопичення інформації для осмислення проблеми пацієнта і пошуку шляхів iї розв’язання, із залученням тактики імпліцитного спонукання до наративу. Оскільки трапляється замовчування, замість запитання психотерапевт ініціює наратив клієнта висловленням радості й готовності вислухати його проблему;

5) стратегію встановлення психологічного контакту з терапевтом і тактику опису поточного емоційного стану;

6) стратегію встановлення емоційного контакту з терапевтом через застосування тактики опису позитивної емоційної реакції на терапевта - But, ah ... (реакція пацієнта підтверджує комунікативну успішність стратегії терапевта - емпатії досягнуто); 
7) стратегію створення психологічного комфорту, яку терапевт кілька разів актуалізує різноманітними тактиками, як, наприклад, тактикою демонстрації усвідомлення емоційного стану пацієнта: пацієнтка замовчує дещо, але усміхається йому - тактика демонстрації позитивної емоційної реакції на терапевта, адже усмішка теж індикатор емоційного стану й наявності контакту.

2. Принцип діалогічності.

Він визначає присутність у терапевтичній ситуації Іншого. Уявлення про Іншого відіграє у психотерапії важливу роль. Так називають і несвідому частину особистості, і певний “негативний ідеал”, який ії водночас лякає та приваблює, а також когось іншого, хто говорить і слухає в екзистенційній ситуації “у присутності Іншого”. Інший буває Інакшим або Чужим. Цей момент надзвичайно важливий, адже відображає комунікативне непорозуміння: комунікант сказав щось, що не мав наміру говорити, а його партнер почув не те, що було вимовлене, або взагалі нічого не почув. Такі явища відображають розкол учасників діалогу. Присутність Іншого є складовою частиною мовлення будь-якого суб'єкта, а такий діалог у психотерапії частіше визначають як протистояння або взаємоспростування, а не взаємодію.

3 іншого боку, структура мовлення забезпечує звучання в лінійності мовного ланцюжка ненавмисної поліфонії, через яку і можна виявити сліди несвідомого. Коли пацієнт говорить, він використовує мову і як спосіб створення двозначності, удаючись до полісемії, омонімії, асоціативних значень, літературних тропів (метафори і метонімії), синтаксичних риторичних фігур. У процесі мовної взаємодії завжди $є$ щось додаткове і непрохане, яке вказує на вторгнення в діалог Іншого. Які ж стратегії й тактики актуалізовані в цьому аспекті?

C4 Uh, well, the main thing I um, want to talk to you about is uh, I'm just newly divorced and uh I had gone in therapy before and I felt comfortable when I left, and all of a sudden now the biggest change is adjusting to my single life. [...] Uh, the biggest thing I want-the thing that keeps coming to my mind I want to tell you about is that I have a daughter, nine, who at one time I felt had a lot of emotional problems. I wish I could stop shaking (T and C: laugh). And uh, I'm real conscious of things affecting her. I don't want her to get upset, I don't want to shock her. I want so bad to- for her to accept me. And we're real open with each other especially about sex. And the other day she saw a girl that was single but pregnant and she asked me all about "can girls get pregnant if they are single?" [...](T:Mhm)

T4 And it's this concern about her and the fact that you really aren't - that this open relationship that has existed between you, now you feel it's kind of vanished?

C5 Yes. I feel like I have to be on guard about that (T: Mhm) because I remember when I was a little girl, when I first found out my mother and father made love, that was dirty and terrible, and I didn't-I didn't like her any more for awhile. And I don't want to lie to Pammy either and I don't know... (Roger's Transcripts, Volume 12, Gloria Interview).

У цих репліках психотерапевтичного сеансу відзначаємо:

1) стратегію об'єктивації проблеми, якої досягають застосуванням тактики формулювання проблеми й тактики роз'яснення обставин, що породжують проблему (Глорія експліцитно сама узагальнено сформулювала свою проблему);

2) стратегію встановлення емоційного контакту з терапевтом через тактику опису емоційного стану (пацієтнка перериває наратив коментарем щодо власного психічного стану). У цьому виявляється імпліцитне прохання співчуття. Лікар сміється разом з Глорією, це вказує на те, що невербально реалізована стратегія створення психологічного комфорту, підтримки, емпатії. Дієвими є також тактика пояснення обставин, що породжують проблему, та тактика наративу в розповіді історії, яка має безпосередній стосунок до виникнення проблеми;

3) стратегію накопичення інформації для осмислення проблеми (тактика уточнення) та стратегію об'єктивації проблеми (тактика перефразування), застосовано перефразування проблеми через риторичні фігури з подальшим погоджуванням; 
4) стратегію об’єктивації проблеми, актуалізовану тактикою підтвердження думки терапевта та тактикою раціонального обгрунтування - асоціативної та раціональної аргументації проблеми: аргументуючи відповідь, Глорія ще раз вже імпліцитно вербалізує проблему.

3. Принцип ідеологічності.

Поняття ідеологія в цьому контексті фігурує як сукупність деяких прихованих ідей, не завжди й не повністю усвідомлюваний вплив яких зумовлює значення висловлювань, що утворюють дискурс. Тут варто визначитися з трактуванням мовного значення крізь призму когніції: значення семантичне й прагматичне не протиставляються, а навпаки - формують єдиний комплекс психічного досвіду. Значення, схоплене знаком, соціально й ситуативно зумовлене й базується на емоційному й тілесному досвіді. Роль мовного знака полягає в активації лексично репрезентованого концепту, що є компонентом семантичної сітки, та в “запуску” інтенціональних / неінтенціональних, усвідомлюваних / неусвідомлюваних інференційних процесів. Ідеї як вторинні ознаки дискурсу розташовуються в просторі конотативної семантики висловів (наявності в них додаткових значень) і мають приховані значення, які мають здатність витісняти очевидні. Урахування конотативних значень сприяє ефективнішому сприйняттю несвідомих ідей (сенсів, мотивів) пацієнта.

C13 Yes (T: Mhm, mhm) and I don't like the ... I would like to feel comfortable with whatever I do. If I choose not to tell Pammy the truth, to feel comfortable that she can handle it, (T: Mhm, Mhm, Mhm) and I don't. I want to be honest, and yet I feel there are some areas that I don't even accept (T: Mhm, Mhm).

T13 And if you can't accept them in yourself, how could you possibly be comfortable in telling them to her?

C14 Right.

T14 Mhm. Mhm. And yet, as you say, you do have these desires and you do have your feelings, but- but you don't feel good about them (Roger's Transcripts, Volume 12, Gloria Interview).

У цьому випадку виокремлюється стратегія об'єктивації проблеми з тактикою роз'яснення, iз залученням риторичних запитань, що безпосередньо пов'язано 3 тактикою переформулювання проблеми, а також стратегія об’єктивації проблеми через тактику перефразування.

Комунікативна успішність психотерапевтичного сеансу безпосередньо залежить від уміння лікаря виявляти приховані значення в дискурсі, інакше реалізація стратегії впливу може завершитися невдачею.

4. Принцип інтенціональності базується на розумінні різноманітних інтенцій клієнта. У людській природі закладено багато прагнень і бажань, які не можна задовольнити одночасно. Крім антагонізму окремих прагнень, очевидні й суперечності між свідомими та неусвідомлюваними цінностями та бажаннями. Усе це відображено в мовленнєвих інтенціях клієнта. Як правило, навіть невеликі фрагменти дискурсу можуть містити кілька різних, часто протилежно спрямованих і навіть взаємоспростовних намірів та прагнень. Процес витіснення визначає основні суперечності, пов'язані з бажанням клієнта одночасно висловити й приховати важливі обставини його особистого життя.

C5 Yes. Ifeel like I have to be on guard about that (T: Mhm) because I remember when I was a little girl, when I first found out my mother and father made love, that was dirty and terrible, and I didn't-I didn't like her any more for awhile. And I don't want to lie to Pammy either and I don't know...

T5 I sure wish I could give you the answer as to what you should tell her. (Smiles.)

C6 I was afraid you were going to say that (Laughs).

T6 Because what you really want is an answer (Roger's Transcripts, Volume 12, Gloria Interview).

У запропонованих висловлюваннях пацієнт погоджується 3 перефразуванням проблеми, що об'єктивується в стратегії об’єктивації проблеми через тактику підтвердження думки 
терапевта. Аргументуючи відповідь, Глорія ще раз вже імпліцитно вербалізує проблему, хоч застосовано тактику раціонального обгрунтування, тобто раціональної аргументації проблеми. У непевних ситуаціях, коли відчутні взаємоспростування чи невизначеність їі прагнень, лікар уміло демонструє невпевненість: він вдається до розігрування непрофесіоналізму задля створення емпатії / комфорту клієнта, що і $\epsilon$ стратегією створення психологічного комфорту.

Стратегія побудови емоційного контакту з терапевтом, а також тактика жарту пацієнтки вербально і невербально виражають симпатію та розуміння, а це означає, що тактика психотерапевта успішна. Не менш важливою є стратегія об'єктивації проблеми через тактику роз'яснення: коли Глорія сказала, чого хоче, вона власне сформулювала проблему, а вербалізація ототожнюється з усвідомленням проблеми, це перший крок до ііі розв'язання.

У процесі аналізу психотерапевтичного дискурсу дифузна кількість висловлювань зводиться до позиційної єдності. Таке перегрупування відповідає певній “точці зародження” дискурсу позиції суб'єкта, яка визначає те, що він може і повинен сказати. Комплекс дискурсивних формацій загалом визначає життєвий світ і межі мовлення клієнта, він детермінований ядром стійких значень, конфігурація яких і формує основу проблеми клієнта.

Наратив суб'єкта апелює до сукупності значень внутрішнього досвіду, використовуючи формули, що конституюють первинний, уявний дискурс у пам'яті. Це виявляється в ритуалах безперервності - поєднанні значень актуальних висловлювань із минулими й майбутніми обставинами, подіями. Такі ритуали характерні також для процесу структуризації тривалої терапевтичної розмови психоаналітичного характеру. Ритуали безперервності співвідносяться 3 формами замовчування: те, що не сказано, теж має сенс.

Процес замовчування пов'язаний із боротьбою значень, що не можуть функціонувати водночас. Вилучення деяких із них із мовлення пацієнта породжує семантичні зони (позиції суб'єкта), які він апріорі не може займати, оскільки психологічно вони стають для нього забороненими. Однак, як засвідчують ілюстративні матеріали дослідження, психотерапевт у таких випадках вільно спілкується з цих позицій, спрямовуючи пацієнта у сферу того, про що він намагався мовчати. Отже, замовчування часто відповідає глибоко витісненим пластам несвідомого. Крім нього, буває також локальне замовчування, що співвідноситься з іррелевантними (неістотними, недоречними) обговорюваній проблемі аспектами досвіду, та замінне замовчування, яке виявляється в намаганні вести мову про одне, щоб не виразити інше.

Висновки й перспективи подальших досліджень.

1. Семантичний простір мови, об'єктивований у системних одиницях мовної картини світу, та характер комунікації взаємовизначаються типом дискурсу, у якому відбувається комунікація, та структурою мовних особистостей.

2. Трактування комунікації під час психотерапевтичних сеансів як мовної форми цілеспрямованої соціальної дії грунтується на діяльнісному розумінні дискурсу. Така інтерпретація прив'язана до кожної конкретної прагматичної ситуації та ментальних процесів терапевта й клієнта, виражених вербально тактико-стратегічним потенціалом.

3. Дослідження мовного аспекту основних принципів аналізу психотерапевтичного дискурсу засвідчує, що, нарівні з вербально вираженими комунікативними стратегіями й тактиками, виявлене замовчування в аналізі психотерапевтичного дискурсу відіграє конститутивну роль, оскільки вказує на важливі складники внутрішнього досвіду суб'єкта.

Отже, порозуміння в комунікації можливе за умови застосування вмотивованого тактикостратегічного потенціалу висловлювань учасників дискурсу та фокусування уваги комунікантів на загальному об’єкті (референті). Важливу роль у цьому відіграють асоціативні зв'язки, у дослідженні яких вбачаємо перспективу подальших наукових пошуків. 


\section{ЛІТЕРАТУРА}

Арутюнова, Н. Д. (1998). Дискурс. Языкознание. Больиой энияиклопедический словарь. Москва. Как нарисовать портрет птицы: методология когнитивно-коммуникативного анализа языка. (2017). Харьков: ХНУ имени В. Н. Каразина.

Кириллова, Е. И. (2010). Интент-анализ психотерапевтической речи. (Дисс. канд. псих. наук). Москва.

Кубрякова, Е. С. (1995). Эволюция лингвистических идей во второй половине ХХ века (опыт парадигмального анализа). Язык и наука конца 20 века. Москва.

Кубрякова, Е.С. (2004). Язык и знание: на пути получения знаний о языке: Части речи с когнитивной точки зрения. Роль языка в познании мира. Москва.

Edmondson, W. (1981). Spoken Discourse: a Model for Analysis. London, New York.

Gumperz, J. J. (1982). Discourse Strategies. Cambridge.

Levy, D. (1979). Communicative goals and strategies: between discourse and syntax. Syntax and semantics. (V.12. - pp.183-210).

Tannen, D. (1993). The relativity of linguistic strategies : Rethinking power and solidarity in gender and dominance. Gender and conversational interaction. New York.

\section{REFERENCES}

Arutyunova, N. D. (1998). Diskurs. Yazykoznaniye. Bolshoy entsiklopedicheskiy slovar. Moskwa. Kak narisovat portret ptitsy: metodologiya kognitivno-kommunikativnogo analiza yazyka. (2017). Kharkov: KhNU imeni V. N. Karazina.

Kirillova, Ye. I. (2010). Intent-analiz psikhoterapevticheskoy rechi. (Diss. cand. psikh. nauk). Moskwa.

Kubryakova, Ye. S. Evolutsiya lingvisticheskikh idey vo vtoroy polovine XX veka (opyt paradigmalnoho analiza). Yazyk i nauka kontsa 20 veka. Moskwa.

Kubryakova, Ye. S. (2004). Yazyk I znaniye na puti polucheniya znaniy o yazyke: Chasty rechi $s$ kognitivnoy tochki zreniya. Rol yazyka v poznaniyi mira. Moskwa.

Edmondson, W. (1981). Spoken Discourse: a Model for Analysis. London, New York.

Gumperz, J. J. (1982). Discourse Strategies. Cambridge.

Levy, D. (1979). Communicative goals and strategies: between discourse and syntax. Syntax and semantics. (V.12. - pp.183-210).

Tannen, D. (1993). The relativity of linguistic strategies : Rethinking power and solidarity in gender and dominance. Gender and conversational interaction. New York.

Дата надходження до редакиії 16.03.2018 p. Ухвалено до друку 27.04.2018 р. 